\title{
Microentrepreneurs' Adoption of E-Payment: A Preliminary Analysis
}

Siti Aishah Mohamad, Salina Kassim

To Link this Article: http://dx.doi.org/10.6007/IJARBSS/v10-i11/8019

DOI:10.6007/IJARBSS/v10-i11/8019

Received: 24 September 2020, Revised: 28 October 2020, Accepted: 21 November 2020

Published Online: 28 November 2020

In-Text Citation: (Mohamad \& Kassim, 2020)

To Cite this Article: Mohamad, S. A., \& Kassim, S. (2020). Microentrepreneurs' Adoption Of E-Payment: A Preliminary Analysis. International Journal of Academic Research in Business and Social Sciences, 10(11), 1042-1048.

\section{Copyright: (c) 2020 The Author(s)}

Published by Human Resource Management Academic Research Society (www.hrmars.com)

This article is published under the Creative Commons Attribution (CC BY 4.0) license. Anyone may reproduce, distribute, translate and create derivative works of this article (for both commercial and non-commercial purposes), subject to full attribution to the original publication and authors. The full terms of this license may be seen at: http://creativecommons.org/licences/by/4.0/legalcode

Vol. 10, No. 11, 2020, Pg. 1042 - 1048

Full Terms \& Conditions of access and use can be found at http://hrmars.com/index.php/pages/detail/publication-ethics 


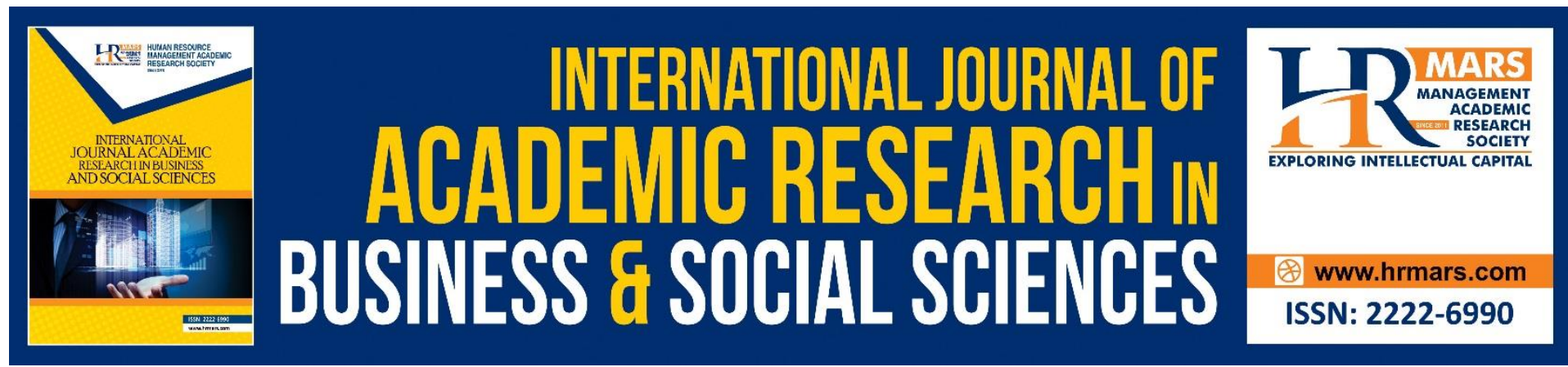

\title{
Microentrepreneurs' Adoption Of E-Payment: A Preliminary Analysis
}

\author{
Siti Aishah Mohamad', Salina Kassim² \\ ${ }^{1,2}$ International Islamic University Malaysia, 'Universiti Teknologi MARA Pahang, Jengka \\ Campus, Pahang, Malaysia
}

\begin{abstract}
This study aims to analyse the e-payment adoption among microentrepreneurs by applying the Unified Theory of Acceptance and Use of Technology (UTAUT). Specifically, the constructs of UTAUT, namely performance expectancy, effort expectancy, social influence, and facilitating conditions are tested against adoption of e-payment of the microentrepreneurs. Additionally, two new variables are included, namely financial cost and technology awareness as an extension of the UTAUT model. Data were collected among microentrepreneurs in Jengka area and being analysed by using SPSS 26.0. The study finds that all the variables have Cronbach's Alpha more than 0.8 which shows that all of them are reliable. The descriptive analysis is done and it was found that all of the respondents surveyed used e-payment in their financial transaction. The study reveals that all respondents used ATM. Almost all of them (91.2\%) used POS terminal, 88.2 per cent used debit card and 2.9 per cent used mobile banking to make payment. However, none of the microentrepreneurs surveyed used internet banking. This study hopes to provide relevant inputs to the relevant authorities on ways to increase the e-payment adoption among microentrepreneurs in Malaysia. In addition, the findings can be used by the academician as a source of reference for their study in the future. Keywords: Microentrepreneur, E-Payment, Adoption, Preliminary Analysis.
\end{abstract}

\section{Introduction}

The world now are at the beginning of Fourth Industrial Revolution, a new era where all sectors are involved in the digital world. The wave of digitalization creates various opportunities for entrepreneurs to improve and strengthen their businesses, particularly the microentrepreneurs. As the market becomes wider and interaction in trading for payments and logistics is based on trusts without face to face meeting, all industry players are scrambling to meet the challenges in the digital world and fulfill changing customers expectations who demand speedy, cost saving and efficient services. One of the important stakeholders in the microenterprise industry is the financial industry. The rapid changes of technology had changed the financial industry all over the world to become digital. All the financial transactions are in the customers fingertips and can be done anytime at anywhere (Victor, 2015). One of the digital banking systems that become more popular is electronic payment (e-payment). The used of machine, card, internet and mobile phone has increased efficiency, innovativeness and reduce fraud in the payment system (Oladeji, 2014). Klapper 
(2017) claimed that the e-payment can increase the microentrepreneurs' profitability by enabling financial transactions to be conducted with customers, suppliers and the government safer, cheaper and efficient.

Even though it has been proven to be successful in certain countries such as Kenya, Bangladesh and India, the adoption of e-payment among the microentrepreneurs in Malaysia is still at low level. E-payment has benefited customers particularly those who are staying in the remote areas to access at least the basic banking services, with emphasis being given to microentrepreneurs whom are categorised as those below 40 per cent of pyramid group (B40). The implementation of e-payment helps the microentrepreneurs to increase the efficiency, reduce cost and optimise their financial operations. Despite the benefits, the adoption of e-payment among the microentrepreneurs are still at the low level. Therefore, it is important to analyse the determinant that influence the e-payment adoption.

This study aims to investigate the adoption of e-payment among microentrepreneurs in Malaysia. To achieve the objective, the Unified Theory of Acceptance and Used of Technology (UTAUT) has been applied as the framework. UTAUT is considered as the best model to analyse the customers' adoption of technology. There are four constructs of UTAUT which are performance expectancy, effort expectancy, social influence and facilitating conditions. The performance expectancy refers to the individuals believe that the use of the technologies will result in better performance because the technology is useful for them. Effort expectancy is referring to the ease of use of the technologies. Facilitating condition is the perception that the organizational and technical infrastructure is required to support the existence of the technologies. Social influence was found as the extent to which individuals perceive that others, especially friends and family, believe they should use e-payment services. A specific example of the adoption of the UTAUT is the study by Vankatesh et. al., (2003) which defined all the constructs and considers them in a model of users' intention and usage of information technology. The model was found to have a coefficient of determination $\mathrm{R}^{2}$ of 0.7 , indicating that the model is able to explain 70 per cent of the variance in the users' intentions and use information technology.

\section{Background}

Small and Medium Enterprises (SMEs) play a vital role in contributing to the output and employment in all countries. In Malaysia, for instance, 78 per cent of the SMEs are microenterprises. Under the new SME definition, microenterprise is defined as a company which has the following characteristics: sales turnover of less than RM300, 000 and number of employees that is less than five persons. Abu Bakar et al., (2012) explained that microenterprises as having less than five full time workers. These small businesses formation obtained licenses or permits from local councils to conduct business and registered with Companies Commission of Malaysia. According to Munoz, Welsh et al., (2014), microentrepreneurs are the small business owners from the isolated segment of population, who set up the business on numerous forms to struggle with the capital constraints and entry barriers. The microentrepreneurs facing difficulties to deal with the formal financial institutions due to the high risk and cost to serving them. In all over the world, the microentrepreneurs have problem to access the external finance and they have more constraints to operate and growth (Galindo \& Schiantarelli, 2003).

The emergence of microfinance institutions (MFIs) contributes the growth of microentrepreneurs. The microentrepreneurs can now access the formal financial institutions for their funding source. As one of the sources of fund to this important group, the MFIs need 
to be prepared with the technological change. The paper-based banking system has been replaced with the paperless system such as the e-payment system, which enables customers from remote areas to conduct banking transactions with less cost. According to Victor (2015), the e-payment helps microentrepreneurs to speed up the payment process because payment will be made directly to the account anytime. Comparatively, in the paper-based system, payment has to be made manually by visiting bank, thus a high travelling cost incurred. The process of trading with customers also can be managed effectively with the e-payment system.

\section{Challenges in the Implementation of e-payment}

Even though there are many advantages of e-payment to the microentrepreneurs, its adoption in Malaysia is still at low level. Different countries are facing different issues in the adoption of e-payment. For example, in Kenya, lack of adequate and reliable infrastructure, inadequate skills due to low levels of computer literacy are listed as some of the challenges for the adoption of e-payment (Ngairah \& Joyce, 2016). Matters related to security, information communication and technology (ICT) literacy, fear of risk, lack of training, awareness, and infrastructure are the problems for the adoption of e-payment in Nigeria (Okifo \& Igbunu, 2015). The study in India found that, innovation of the system, incentive (monetary and nonmonetary), customer convenience and legal framework are the four factors that need to be highlighted to increase the e-payment adoption (Sanghita \& Indrajit, 2014).

Additionally, e-payment requires cost and ICT skill for it to be used by users. The rapid changes of technology create difficulties for microentrepreneurs to adopt. Customers who have no experience and knowledge fear to use e-payment system (Meuter et al., 2003). They will only adopt the new technology system if it has clear benefit and comfortable to use (Norris \& Moon, 2005; Titah \& Barki, 2006; Gupta et al., 2019). Staying in the remote area and busy with the business maybe make the microentrepreneurs not aware with the new payment system. Although the Central Bank of Malaysia (CBM) organised the National epayment township road shows to create awareness about e-payment, it is not focusing to the poor communities. The road shows were held in the city areas around Malaysia. As the consequence, the poor communities were legged behind the technological change and cannot adopt because not aware of it. The previous studies concluded that awareness leads to slow adoption of e-payment (Yaqub, et al., 2013). Few studies found that technology awareness is significantly influenced the adoption of electronic payment system (Abu Bakar et al., 2013; Rehman et al., 2012). The study by Min et al., (2020) revealed that facilitating condition as one of the strongest predictors of behavioral intention to use e-payment. The facilitating condition such as ICT facilities to access the internet are also the problem to the microentrepreneurs. Even though the 1Malaysia Internet Centre was set up by Malaysian Communications and Multimedia Commission (MCMC), but this facility benefited specifically for students from the rural areas (MCMC, 2016).

\section{Research Methodology}

As a preliminary analysis, this study adopts a pilot study which is important to identify the weaknesses in survey techniques and questionnaires (Kothari, 2004). According to Monette et al., (2011), a minimum of twenty participants for the pilot test are sufficient to test the validity of the questionnaires content. The respondents of this study are the microentrepreneurs and also the MFI clients who are staying around Bandar Pusat Jengka; a 
small town in Pahang state of Malaysia. For the purpose of this study, a survey was conducted among 34 microentrepreneurs. The questionnaires consist of two sections; Section $A$ is the demographic profile of respondents and Section $B$ is about the determinants of e-payment adoption. The items in Section B were measured using a 7-point Likert scale, ranging from "strongly disagree" to "strongly agree. Statistical Package for the Social Sciences (SPSS) 26.0 was used to run the analysis.

\section{Results and Discussion}

The demographic profile of the microentrepreneurs has been investigated in Section A of the questionnaire. It was found that, each of the single and married respondents are 38.2 per cent respectively. Another 23.6 per cent are single parents. Most of the microentrepreneurs $(67.6 \%)$ has the secondary school qualification. Four $(11.8 \%)$ of them only have primary school qualification. The rest $(20.6 \%)$ are the diploma and bachelor's degree holders. The descriptive analysis was done and it was found that all of the respondents surveyed used e-payment in their financial transaction. In particular, the study reveals that all respondents used Automted Teller Machine (ATM). Almost all of them (91.2\%) used debit card to make payment. Point of Sales (POS) terminal also has high usage rate $(88.2 \%)$ because most of the respondents are the clients of Amanah Ikhtiar Malaysia (AIM). AIM provides POS terminal to their clients for repayment of loan. Few respondents are found (2.9 per cent) used mobile banking. However, none of the microentrepreneurs surveyed used internet banking. This is maybe due to the slow internet connection in Jengka area.

The reliability test has been conducted to ensure that the six variables; performance expectation, effort expectation, social influence, facilitating conditions, financing cost and technology awareness are reliable. Referring to Table 1, all the variables have the Cronbach's Alpha more than 0.8. It means that these constructs are reliable. The value of Cronbach's Alpha must be more than 0.7 to ensure that variables are reliable (Hair et al., 2007).

Table 1. Reliability Statistic

\begin{tabular}{|l|c|c|}
\hline Variables & Cronbach's Alpha & No of Items \\
\hline Performance Expectations & 0856 & 6 \\
\hline Effort Expectations & 0.847 & 6 \\
\hline Social Influence & 0.899 & 6 \\
\hline Facilitating Conditions & 0.841 & 6 \\
\hline Financing Cost & 0.848 & 5 \\
\hline Technology Awareness & 0.853 & 5 \\
\hline E-Payment Adoption & 0.880 & 5 \\
\hline
\end{tabular}

From the data analysis, it can be concluded that all the microentrepreneurs adopt epayment. However, most of them are comfortable using the old version of e-payment platforms such as ATM and debit cards. The ATM was firstly introduced in the early 1980s. While the debit card was first time issued in 2004. These two platforms do not need the internet network or use of the communication devices. While the POS terminal is used by them because of this platform provided by the MFIs purposely for the loan repayment. The microentrepreneurs did not use internet banking may be due to slow internet coverage. The microentrepreneurs in Jengka area are facing the same problem as Kenya and Nigeria. They were unable to use internet banking to make payments due to the poor internet connection around their premises. To encourage the e-payment adoption specifically on internet banking 
and mobile banking, the government should play their role to improve internet connection in Jengka area. As stated by Min et al., (2020) facilitating condition such as internet facility is one of the strongest predictors of behavioral intention to use e-payment.

Further study should be conducted to know the factors that really influence the epayment adoption. From the discussion in the challenges of e-payment implementation, six factors were suggested. The result of the reliability test on suggested factors; performance expectation, effort expectation, social influence, facilitating conditions, financing cost, and technology awareness shows that the six factors are reliable because the Cronbach's Alpha values are more than 0.8 . The measurement model and structural model ssessments can be conducted to know the relationship between all the factors with e-payment adoption. These tests are very important and can contribute to literature review for e-payment adoption. In addition, it also can provide information to the MFIs and Government in encouraging the B40 groups to use e-payment.

\section{References}

Darwish, S., Ahmed, U., \& Pahi, M. H. (2020). Innovative Work Behavior During COVID-19 for Medical Representative in the Pharmaceutical Industry: Test of a Moderation Model in Bahrain. International Journal of Pharmaceutical Research. 12(4), 19271934. doi.org/10.31838/ijpr/2020.12.04.277

Galindo, A., and Schiantarelli, F. (2003), Credit Constraints and Investment in Latin America, RES Working Papers 4305, InterAmerican Development Bank, Washington D.C.

Garson, G. D. (2012). Testing statistical assumptions (12th ed.). Asheboro: Statistical Associates Publishing.

George, D., \& Mallery, P. (2005). SPSS for windows step by step: A simple guide and reference, 12.0 update (5th ed.). Boston, MA: Pearson Education.

Gupta, K. P., Manrai, R., \& Goel, U. (2019). Factors influencing adoption of payments banks by Indian customers: Extending UTAUT with perceived credibility. Journal of Asia Business Studies, 00-00. doi:10.1108/jabs-07-2017-0111.

Hair, J. F., Money, A. H., Samouel, P., \& Page, M. (2007). Research Methods for Business. Chrichester. West Sussex: John Wiley \& Sons, Inc.

Kothari, C. R. (2004), Research Methodology: Methods and Techniques, (Second Edition), New Age International Publishers.

Meuter, M. L., Ostrom, A. L., Bitner, M. J., \& Roundtree, R. (2003). The influence of technology anxiety on consumer use and experiences with self-service technologies. Journal of Business Research, 56(11), 899-906. https://doi.org/10.1016/S01482963(01)00276-4.

Min, Y. L., Jing, H. K., \& Ming, M. L. (2020). Examining the antecedents of customer adoption and intention to use mobile wallet: an empirical investigation.Proceedings of the 2020 11th International Conference on E-Education, E-Business, E-Management, and E-LearningJanuary $2020 \quad$ Pages 380-384https://scihub.tw/https://doi.org/10.1145/3377571.3377613.

Monette, D. R., Sullivan, T. J., \& Dejong, C. R. (2011). Applied social research:a tool for the human services. New York: Brooks/Cole Cengage Learning.

Munoz, J. M., Welsh, D. H. B., Chan, S. H., Raven, P. V. (2014). Microenterprises in Malaysia: a preliminary study of the factors for management success. International Entrepreneurship and Management Journal. doi: 10.1007/s11365-014-0302-y. 
Norris, D. F., \& Moon, M. J. (2005). Advancing E-government at the grassroots: Tortoise or hare? Public Administration Review, 65(1), 64-75. DOI: 10.1111/j.15406210.2005.00431.x.

Oladeji, K. (2014). Integrated personnel and payroll information systems (IPPIS) for Universities and other higher institutions of learning. A paper presentation at Northwest University, Kano - Nigeria.

Roy, S., and Sinha, I. (2014). Determinants of customers' acceptance of electronic payment system in Indian banking sector - A Study. International Journal of Scientific \& Engineering Research, Volume 5 (1), pp 177-187.

Titah, R., \& Barki, H. (2006). E-Government adoption and acceptance. International Journal of Electronic Government Research, 2, 23-57 http://dx.doi.org/10.4018/IJEGR.

Venkatesh, V., Morris, M. G., Davis, F. D., \& Davis, G. B. (2003). User acceptance of information technology: Towards a unified view. MIS Quarterly, 27, 425-478.

Victor K. (2015). Online banking services \& benefits to merchants. BNM Payments System Forum 2015.

Yan, X., \& Su, X. G. (2009). Linear regression analysis: Theory and computing. Singapore: World Scientific Publishing Co. Pte. Ltd.

Yaqub, J., Bello, H. T., Adenuga, I. A., \& Ogundeji, M. O. (2013). The cashless policy in Nigeria: Prospects and challenges. International Journal of Humanities and Social Science, $3(3), 200-212$. 